\title{
In diens van die Kompanjie
}

\author{
Kol. (dr.) Jan Ploeger*
}

\begin{abstract}
In sy "Daghregister" het opperkoopman Jan van Riebeeck op 6 April 1652 onder andere aangeteken dat hy opdrag aan skipper D. Coninck gegee het om op die volgende dag (7.4.1652) met ' $n$ sloep na die vasteland te gaan. Die doel van hierdie tog was om na briewe te soek wat deur besoekende skepe agter gelaat is. Ook moes groente gehaal en vars vis gevang word. Behalwe die roeiers sou 'n sestal gewapende soldate die skipper vergesel.
\end{abstract}

Dit is die eerste vermelding in die dagregister van die aanwesigheid van soldate, as 'n deel van die VOC se krygsmag, aan die Kaap die Goeie Hoop. In bygaande bydrae word o.m. nader op soldate en skepe, in diens van die VOC, ingegaan.

"The people's triumphant emergence from a perilous war against the superior power of the Spanish Empire had given them a self-confidence that hesitated at no enterprise which promised abundant award for their daring."

- Prof. A.J. Barnouw: The Netherlands (Berkeley, Los Angeles, 1943, p. 39).

Toe die Tagtigjarige Oorlog (1568-1648) in die guns van die Nederlandse republiek begin verloop het, het die Nederlandse seevaarders en handelaars meer en meer die spreekwoordelike vyf wêrelddele en sewe oseane van die wêreld met hulle handelskepe begin besoek. Hulle het op dié wyse die vragvaarders van Europa geword en wyn van Frankryk na die Oosseelande vervoer, en daar graan en hout gelaai om elders af te laai. Hulle het Engelse hawens besoek, die Middellandse seegebied deurkruis, en walvisse in die omgewing van die eiland Spitsbergen gevang.

Verder het hulle, in die loop van die $17 \mathrm{de}$ eeu, ' $n$ nedersetting aan die Kaap die Goeie Hoop gestig en tydelik aan die kus van Brasilië verskyn. Hulle vlag, die driekleur, het gewapper in die Karibiese see, aan die noordkus van Suid-Amerika en op die eiland Manhattan, die kern van die latere Nieu-Amsterdam (New York).

Oos van die Kaap die Goeie Hoop het Nederlandse skepe aan die wes- en ooskus van Indië (Malabar, Coromandel), by die eiland Ceylon en in die hawens van Maleia, Oos-Indië en Japan hulle verskyning gemaak.

Tasmanië is vernoem na die Nederlandse ontdekkingsreisiger Abel Tasman (1602-1659). Hy het tussen 1642 en 1644 die "Suidland", t.w. Australië, Nieu-Seeland en Van Diemensland

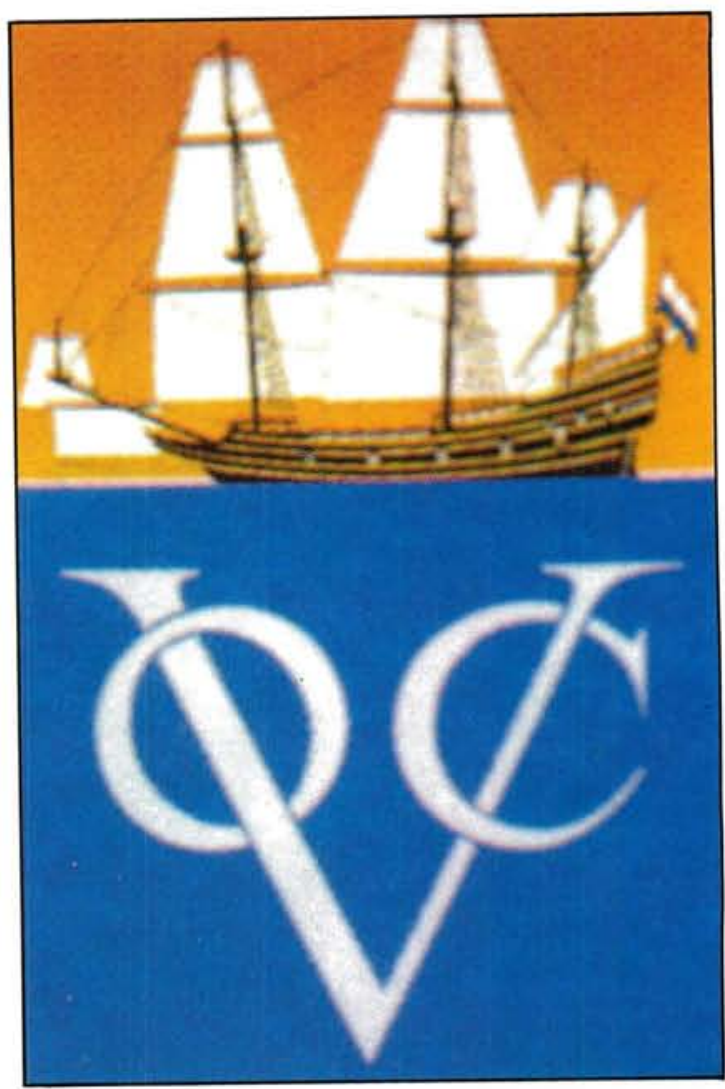

Embleem in verband met die bou van die "Batavia" te Lelystad, Nederland

(Tasmanië) ontdek. Kaap Hoorn, aan die suidpunt van Suid-Amerika, is deur skipper Willem Schouten (oorlede in 1625, Madagaskar) na sy geboortestad vernoem. Die name Spitsbergen, die Barentszsee, Tafelbaai en Dasseneiland, om slegs ' $n$ paar te noem, hou almal verband met Nederlandse handelsreise.

In 1939 het Peter Bricklayer in Holland's House A nation buidling a home (Haarlem, 1939), in 'n kernagtige paragraaf, die drang om die wêreld te verken, soos volg verduidelik: 


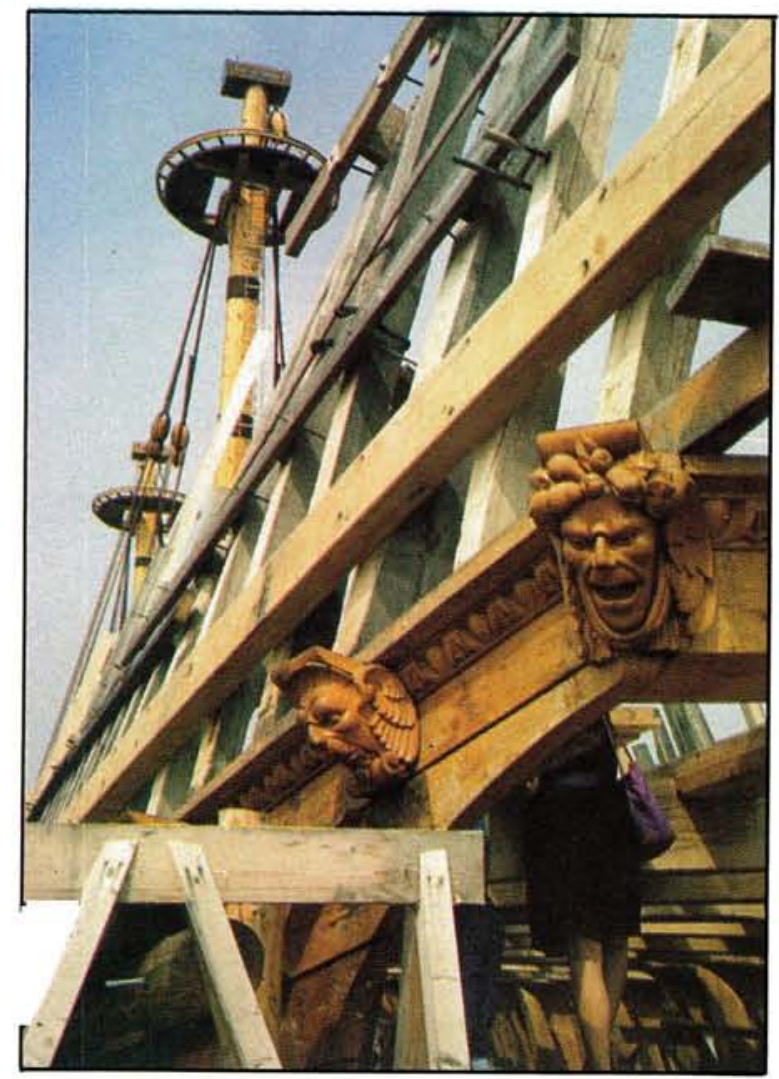

'n Foto van naby van die replika van die VOC-skip "Batavia". Die twee maste is, gedeeltelik, geplaas. Let op die versierde koppe, pragtige voorbeelde van houtsnykuns. Die oorspronklik bewapende koopvaardyskip het op sy eerste uitreis (1629) naby die kus van Wes-Australië vergaan. (Foto: Mnr. E. Struif Bontkes)

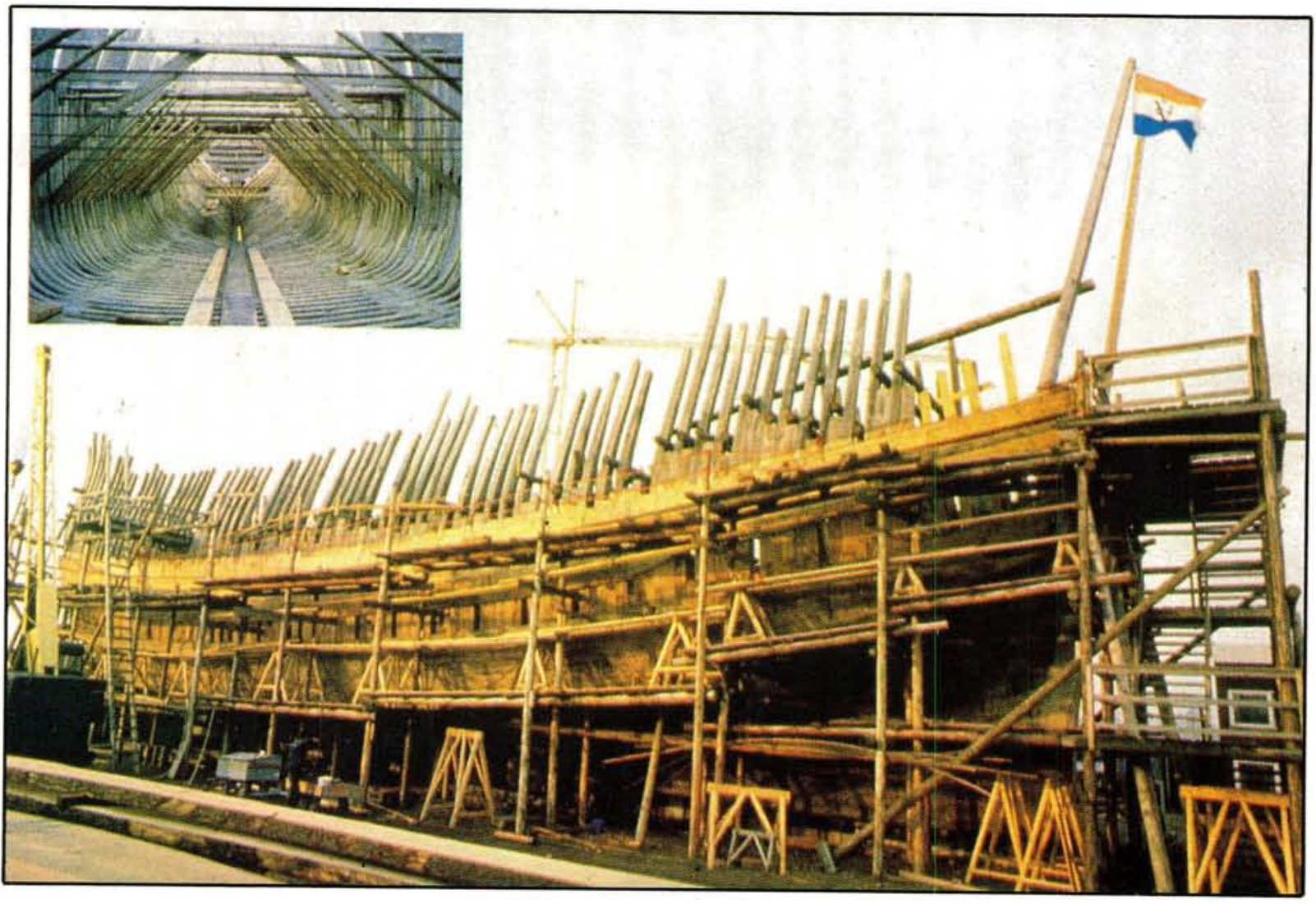

Aan die Oostvaarderdijk (Lelystad) word 'n replika van die spieël-retoerskip "Batavia" op ware grootte gebou. Die skip het ' $n$ lengte van ruim $56 \mathrm{~m}$. en 'n breedte van ruim $10 \mathrm{~m}$. Verwag word dat die vaartuig in 1992 gereed sal wees. Met die bou is in 1985 begin. 
"The man who lives behind a dike, is like a mountaineer: he wants to climb on top to scout for a wider horizon. And if the other side is water, he feels inclined to go and explore it, especially if his little bit of soil offers only limited possibilities for self sufficiency.

So the Dutch took to the water, down to the sea in ships, and ventured out, far away, under strange stars" (p. 33).

Om hierdie reise te kon onderneem was 'n deeglike kennis van die seevaart, kennis van skeepsbou, matrose, soldate, bestuurders en bo alles kapitaal benodig.

\section{Die Nederlandse handel en seevaart}

In die waterland Nederland was die vroeë bevolking reeds na die see gelok. Amsterdam was aanvanklik 'n vissersdorpie. Omstreeks 1250 het, in dié omgewing, die handel en skeepvaart met naburige landstreke begin ontstaan. Namate hierdie bedrywighede begin ontwikkel het, het die behoefte plaaslik ontstaan om, op eie skeepswerwe, nuwe skepe te bou en beskadigde vaartuie op te knap. Skeepsrompe is op werwe skoongemaak om skepe vinniger te laat seil en van nuwe touwerk en seile te voorsien.

In die loop van die 16 de eeu het die uitbreiding van die Nederlandse seilvaart in die noordelike waters van Europa, die Middellandse seegebied en elders begin toeneem. Skeepsreise soos die wêreldreis van Olivier van Noort (1598-1601) is onderneem. Die seeprovinsies Holland en Zeeland het skepe op die Oosterse vaart (die Oossee), die Straatvaart (die Middellandse see), Noord-Afrika, Spanje, Portugal, die destydse Spaanse en Portugese kolonies, sowel as na Oos-Asië uitgestuur.

Voorbeelde van dié uitbreidingsdrang was die aankoms van 'n Nederlandse handelskip in Brasilië (1594) en Angola (1593), Cornelis de Houtman se verkenningstog aan land oos van die Kaap die Goeie Hoop (6.8.1595), die besoek van Nederlandse seelui aan Rio de Janeiro (1598-1601), die Kongorivier (1607) en Manhattaneiland (1610).

Voeg daarby gebeurtenisse soos die stigting van Batavia (1619, vandag Djakarta), en die totstandkoming van handelsmaatskappye soos die Verenigde Nederlandse Geoktrooieerde Oos-Indiese Kompanjie (VOC; 1602), die Groenlandse Kompanjie (1614) en die Wes-Indiese Kompanjie (WIC, 1621). Dit alles gee 'n beeld van die destydse omvang en arbeidsveld van die Nederlandse handel en skeepvaart, sowel as van die uitbreidings- en vestigingsdrang in die wêreld.

Daar was ' $n$ uittog van Antwerpen van vooraanstaande, kapitaalkragtige en ondernemende Vlaamse en Brabantse Calviniste na die noordelike seeprovinsies nadat dié belangrike sentrum van handel en skeepvaart in 1585 in Spaanse hande geval het. Hierdie voorval het die stad Amsterdam en ander stede ten goede gekom en die gesketste ontwikkeling bevorder.

\section{Die skeepsbou}

As gevolg van hierdie uitbreidingsdrang het daar in Amsterdam ' $n$ besondere voorstad, die "Lastage", met pakhuise, skeepswerwe, lynbane, houtsaerye, teerkokerye, ankersmederye, seilmakerye en soortgelyke bedrywe ontstaan.

Die VOC het, van 1608-1660, sy eie skeepstimmerwerf op die Rapenburg. Amsterdam, besit. Daar is die vernaamste pakhuis van die Kompanjie, die "Oostindisch Magazijn", timmerloodse, smidswinkels, 'n skeepswerf ensovoorts opgerig.

Terselfdertyd het daar, ook in ander dele van die land, skeepsbousentrums van betekenis verrys.

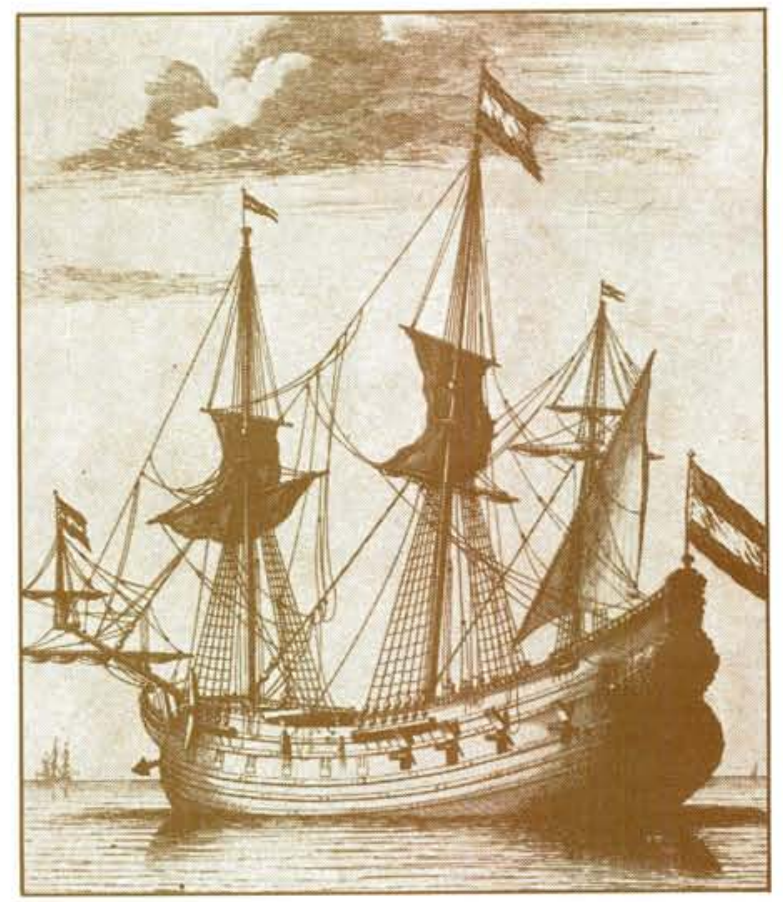

'n Fluitskip uit die tweede helfte van die 17 de eeu 
Behalwe handelskepe is ook oorlogskepe, vissersbote en vaartuie vir die binnevaart gebou.

Daar is bereken dat, omstreeks 1600 , die Nederlandse republiek, op 'n bevolking van 1,5 tot 2 miljoen inwoners, tussen 15000 en 20000 skepe besit het. Daar is 1000 seeskepe per jaar gebou, waarvan die fluitskepe en die spieëlskepe die vernaamste was.

Die eerste fluitskip, ' $n$ driemaster met 'n tonnemaat van 400, was die belangrikste koopvaardyskip op die Europese skeepvaartroetes. Die eerste van hierdie kenmerkend Nederlandse skepe is in 1595 in die stad Hoorn vervaardig.

Ander seeskepe was die reeds genoemde spieëlskepe. Hulle het oor 'n hoë agterskip beskik wat plat aan die agterkant was. Die boonste gedeelte van hierdie kant, die spieël, was met beeldhouwerk versier. Die tonnemaat van hierdie skeepsoort, wat ook op die roete rondom die Kaap die Goeie Hoop verskyn het, was tussen 500 en 1000 ton.

Die VOC se skeepswerf het, in jare van voorspoed, meer as 1200 gespesialiseerde werkers in diens gehad.

Behalwe die genoemde skeepsoorte was daar nog die linieskepe. Dit was lang skepe met ' $n$ stewige romp en hoë maste. ' $n$ Jag was 31 tot ruim $42 \mathrm{~m}$. lank, $8,5 \mathrm{~m}$. breed en sy laaivermoë was 80 las ( 1 las $=2000 \mathrm{~kg}$. gewig).

Vooruitgang op die gebied van die skeepsbou het ook aanhoudende verbeteringe op die gebied van die navigasie- of seevaartkunde en die stuurmanskuns meegebring, terwyl toenemende betroubaarheid van seekaarte en ander vakkundige bronne van kennis die groot seevaart oor die oseane van die wêreld voortdurend begunstig het.

Skepe het vergaan! Daar was die Batavia, waarna later verwys word. Die VOC-skip De Liefde is in 1698 in Amsterdam gebou en het drie reise om die Kaap die Goeie Hoop na Batavia en terug voltooi. Tydens sy vierde uitreis van Texel na Batavia, in 1711, het De Liefde by die Shetland-eilande met ' $n$ bemanning van 200 matrose, 100 soldate en ' $n$ hoeveelheid ammunisie vergaan. Dit was ' $n$ skip van $50 \mathrm{~m}$. lengte en 'n tonnemaat van 500 . Die bewapening het uit 40 vuurmonde van verskillende kaliber bestaan. Die vaartuig se breedte was ongeveer $13 \mathrm{~m}$. en sy diepgang ruim $5 \mathrm{~m}$. Handelskepe was, met die oog op seerowery en vyandige nasies, bewapen.

Die Hollandia, 'n skip van 700 ton, het ook vergaan. Dié vaartuig is in 1743 in Amsterdam te water gelaat en het in die volgende jaar, op sy uitreis, by die Scilly-eilande, verongeluk. Aan boord was kaptein Jan Kelder, ' $n$ bemanning van 276 en ' $n$ aantal soldate. Onder die dertig passasiers was 'n broer van goewerneur-generaal Gustaaf Willem, baron Van Imhoff (17051750) wat in 1743 ' $n$ kort reis deur die Kaapse binneland onderneem en ' $n$ verslag van sy bevindings opgestel het. Dit is interessant om te weet dat die wrak van die Hollandia in 1971 opgespoor is.

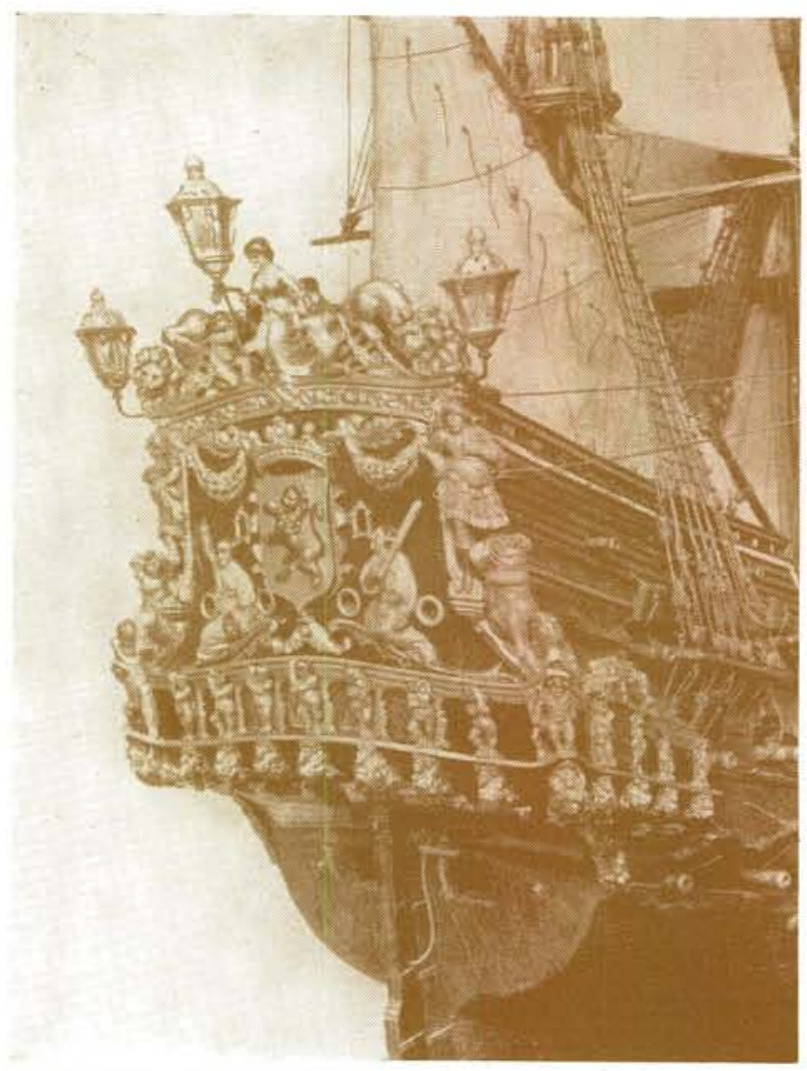

Die versierde spieël van die model van die admiraalskip Hollandia (1665)

Skepe en matrose het tydens storms omgekom. Duisende het hulle lewens in diens van die VOC opgeoffer. Hulle het as gevolg van siektes, in gevegte, deur toediening van swaar liggaamlike strawwe, deur eensydige voedsel en as gevolg van heimwee hulle graf in die golwe of aan onbekende strande gevind. 


\section{Die bewapening en die gebruik van VOC- skepe}

Nadat die romp van 'n skip op die skeepswerf voltooi is, het die tewaterlating gevolg. Daarna is die vaartuig geleidelik vir gebruik gereed gemaak. Ten opsigte van die bewapening het die stad Amsterdam aan die begin van die $17 \mathrm{de}$ eeu oor twee munisipale geskutgieterye beskik. Tewens is, in die loop van dieselfde eeu, die vervaardiging van harnasse en handvuurwapens, sowel as van geweer-, karabyn- en pistoollope in die stad ter hand geneem. Die bewapening van handelskepe was ligter as dié van oorlogskepe. In De Vloot van De Ruyter (Bussum, 1971) verwys die outeur, dr. C.M. Schulten, na swaar kanonne aan boord van oorlogskepe, waarvan die skietafstand tussen 400 en $800 \mathrm{~m}$. bedra het. Die gewig van die koeëls van hierdie vuurmonde was 32 pond. Hulle was van yster gemaak. Dr. Schulten vermeld verder o.m. dat die vuursnelheid van so 'n kanon ses minute vir elke skoot was. Tien tot twaalf persone was nodig om so ' $n$ vuurmond te bedien (pp. 52-53). Daar was verder o.m. gewere, byle, sabels en pistole, sowel as pieke en ander vuur-, steek- en slagwapens aan boord.

Die VOC was die grootste handelsmaatskappy van die destydse wêreld. Die handelsgebied van hierdie organisasie het van suidoos-Asië, Ceylon, Indië en Persië tot by Kaapstad uitgestrek.

Soos bekend was die hoofkantoor en die hoofbestuur van die VOC, Here XVII, in Amsterdam gevestig met takkantore of "kamers" in Rotterdam, Delft, Hoorn, Enkhuizen en Middelburg. Met eie skepe is onder andere die volgende handelsware in Nederland of elders ingevoer: Peper, gemmer, muskaatneute, naeltjies, onbewerkte sy, tekstielware, koper, sink, tin, indigo (blou verfstof), salpeter, koffie en tee. Belangrik was die invoer in Nederland van rietsuiker, afkomstig van Java, wat ook deur VOC-skepe na Sjina en Persië vervoer is. Van Sjina is poeiersuiker met VOC-vragskepe weer na Nederland gebring.

As gevolg van die invoerartikels het daar in $\mathrm{Ne}$ derland bewerkingsnywerhede ontstaan, soos suikerraffinaderye en bedrywe waar wol, seep, sout, glas en aluin verwerk en bier gebrou is.

Uitvoerprodukte wat gedeeltelik uit voortbrengsels van eie bodem bestaan het, was suiwelprodukte, vis, bier, likeur, jenewer, seep, suiker, sout, tabak, papier, geverfde tekstielware, meubels, glasware en erdewerk.

Verskillende skrywers het opgemerk dat die VOC-skepe dikwels te swaar gelaai was as gevolg van kanonne en skeepsvrag. Verder het hulle aangevoer dat daar te weinig ruimte vir siekes en gewondes aan boord van die skepe was.

\section{Die bemanning}

Veelvuldige redes is aangevoer vir die besluit van duisende om as matrose, soldate, amptenare of in ander beroepe in diens van die VOC te tree. 'n Paar van dié redes was: Seuns uit groot gesinne kon nie altyd in eie kring aan die slag kom nie. Ander het teenslag op besigheidsgebied of andersins gehad en besluit om hulle geboorteland vaarwel te sê. Weer ander het gevlug vir die hand van die gereg. Dan was daar Nederlanders, en veral Duitsers sowel as verteenwoordigers van ander nasionaliteite, wat nie daarin kon slaag om 'n geskikte werkkring in eie land te vind nie. Ander is gelok deur droombeelde van avontuur en groot rykdomme agter die horison.

Die meerderheid van die soldate was nie Nederlanders nie, maar vreemdelinge. Onder hulle was avonturiers en afgedanktes. Veral Duitsers is deur hulle vorste aan die sogenaamde "ronselaars" (werwers) verkoop.

Dié troepe was aanvanklik sonder uniforms en moes in Oos-Indië of elders die stryd teen die inheemse bevolking sowel as Portugese, Spanjaarde en Engelse mededingers van die VOC, aanknoop.

Aan die Kaap die Goeie Hoop moes hulle, soos elders, die belange van die VOC beskerm en verdedig. Ook hier was Nederlandse soldate, soos in ander lande, in die minderheid. In dié verband verklaar prof. C.R. Boxer in sy voortreflike studie The Dutch Seaborne Empire 1600-1800 (London, 1965, p. 80) dat die Kaapse garnisoen o.m. uit Engelse, Skotse en lerse soldate bestaan het, maar dat - soos elders - Duitsers die meerderheid gevorm het. Dit was die toestand in 1660 . Van 1728 tot 1740 was Johannes Tobias Rhenius, 'n gebore Berlyner, in bevel van die Kaapse garnisoen (p. 81).

Met die doel om soldate en matrose vir die VOC vir diens te werf, het 'n groep ronselaars of "ziel- 


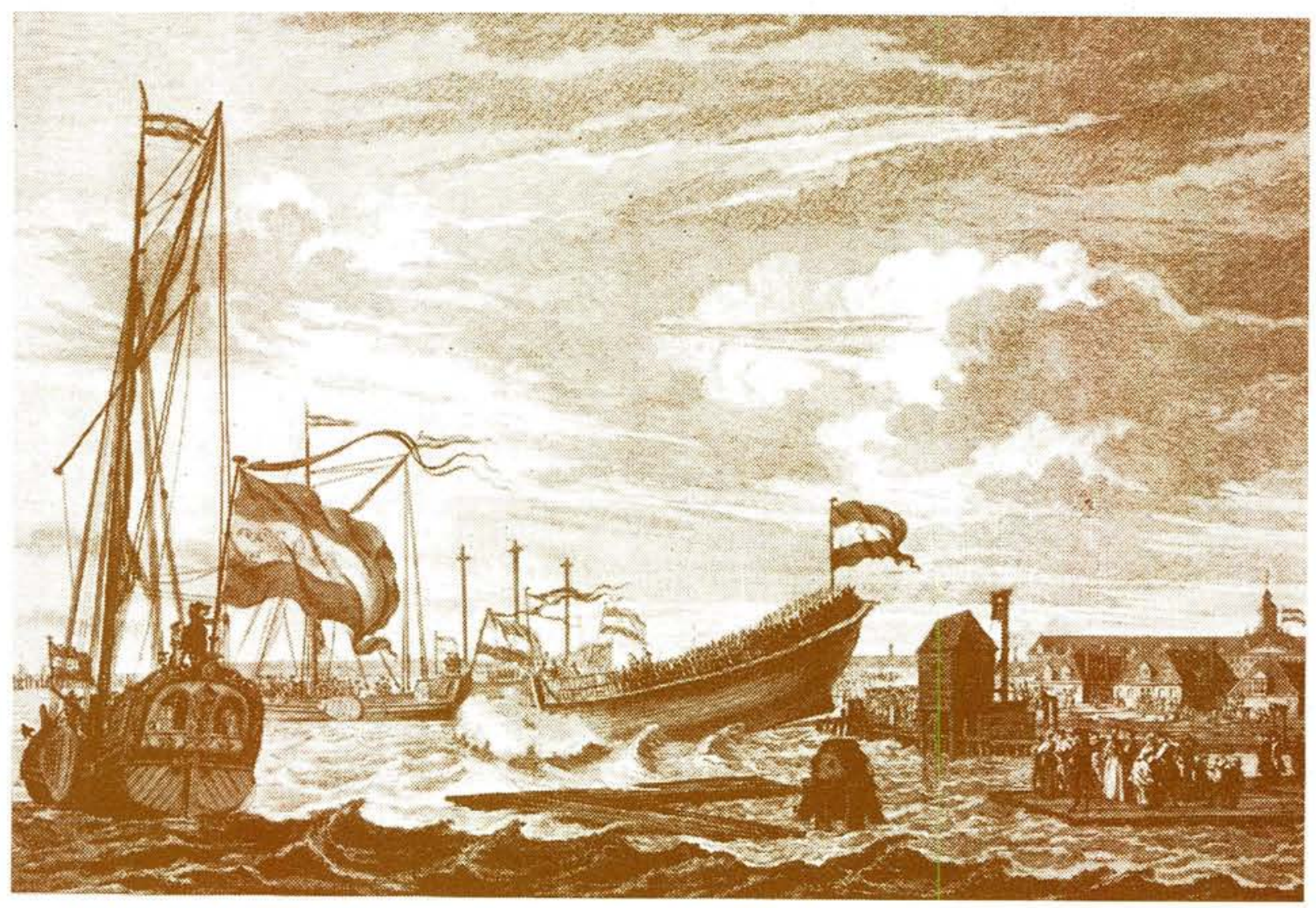

In 1768 is die hoekerskip De Zon op die skeepswerf van die VOC in Amsterdam (Oostenburg) te water gelaat

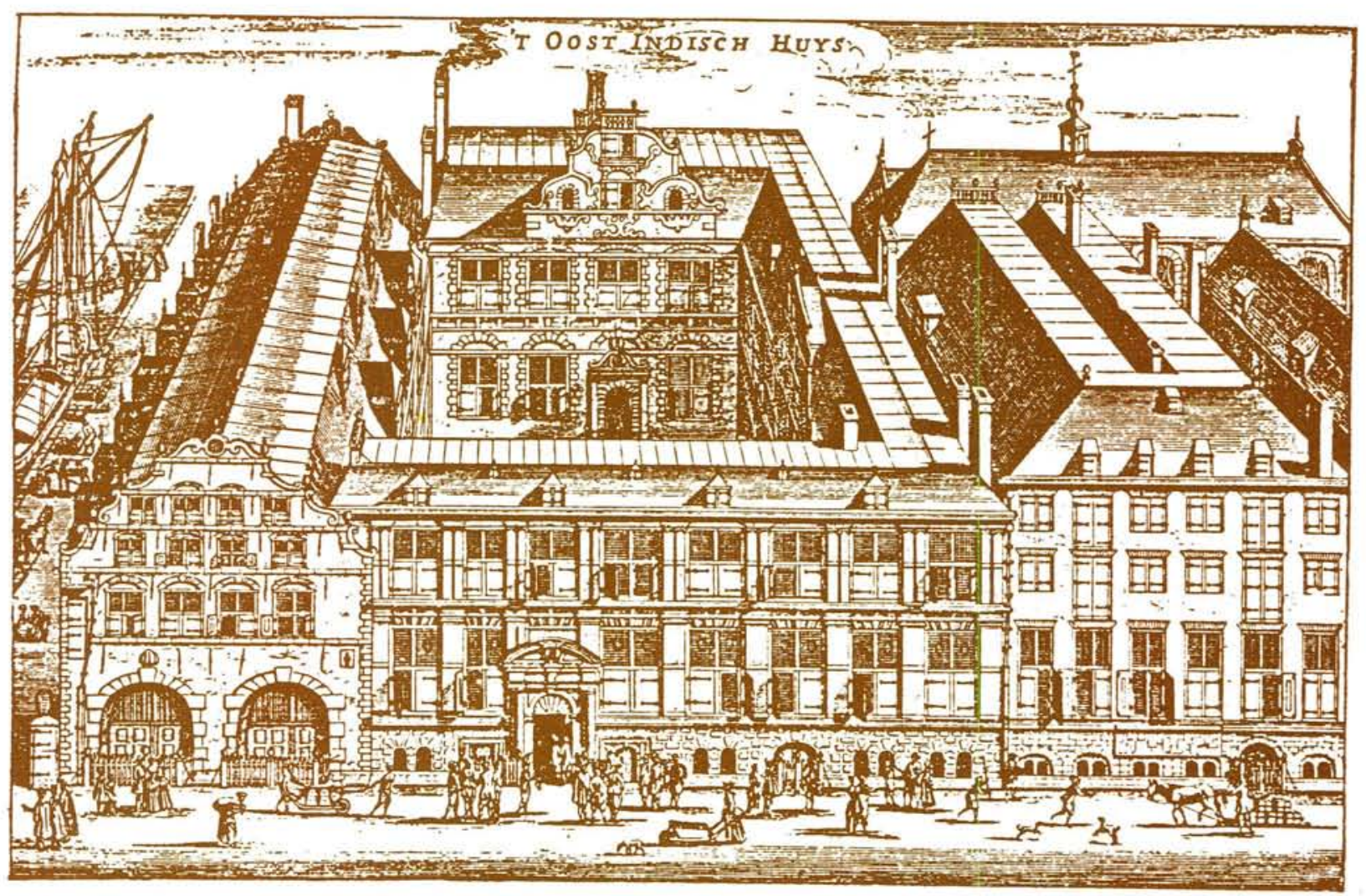

Die voormalige hoofkantoor van die VOC aan die Hoogstraat, Amsterdam. Die oorblywende deel van die gebou staan tans as "Oost-Indisch Huis" bekend 


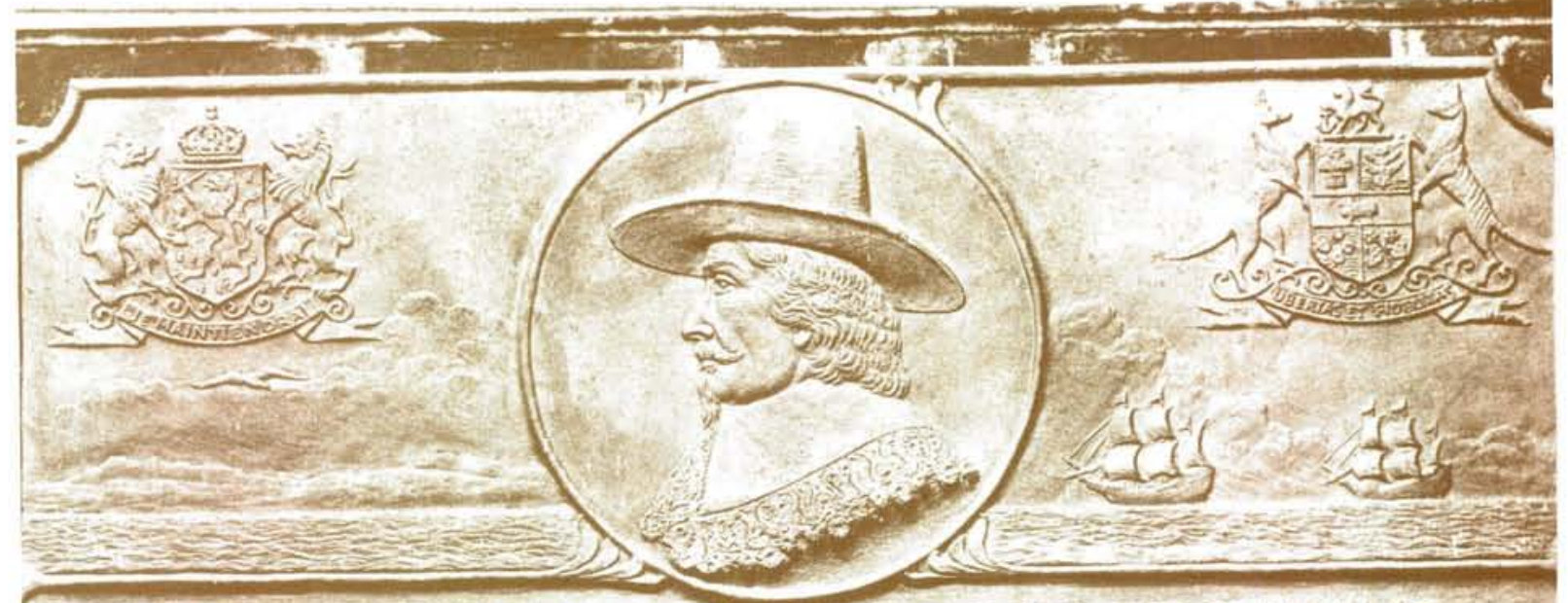

DE REGERING VAN TASMANIA TEEFT DEZE GEDENKPLAAT IATEN AANERENGEN TER HERINNERING AAN DE ZEEVAARDER ADEI JANSLOON TASMAN, GEBOREN TE LUTJEGAST IN 1603, ONTDEKKER VAN TASMANIA OP 24 NOVEMBER 1642 .

THIS PLAQUE IS ERECTED BY THE GOVERNMENT OF TASMANIA IN MEMORY OF ABEL JANSZOON IASMAN, NAVIGATOR, BORN AT EUTJEGAST IN 1603. DISCOVERER OF IASMANIA 1-n-2 Tस:

Gedenkplaat aan die kerk van Lutjegast, prov Groningen, Nederland, ter herinnering aan Abel Tasman (1602-1659), seevaarder in diens van die VOC, en ontdekker van Nieu-Seeland en Tasmanië (Van Diemensland) (Foto: Dr. L.H. Bruins)

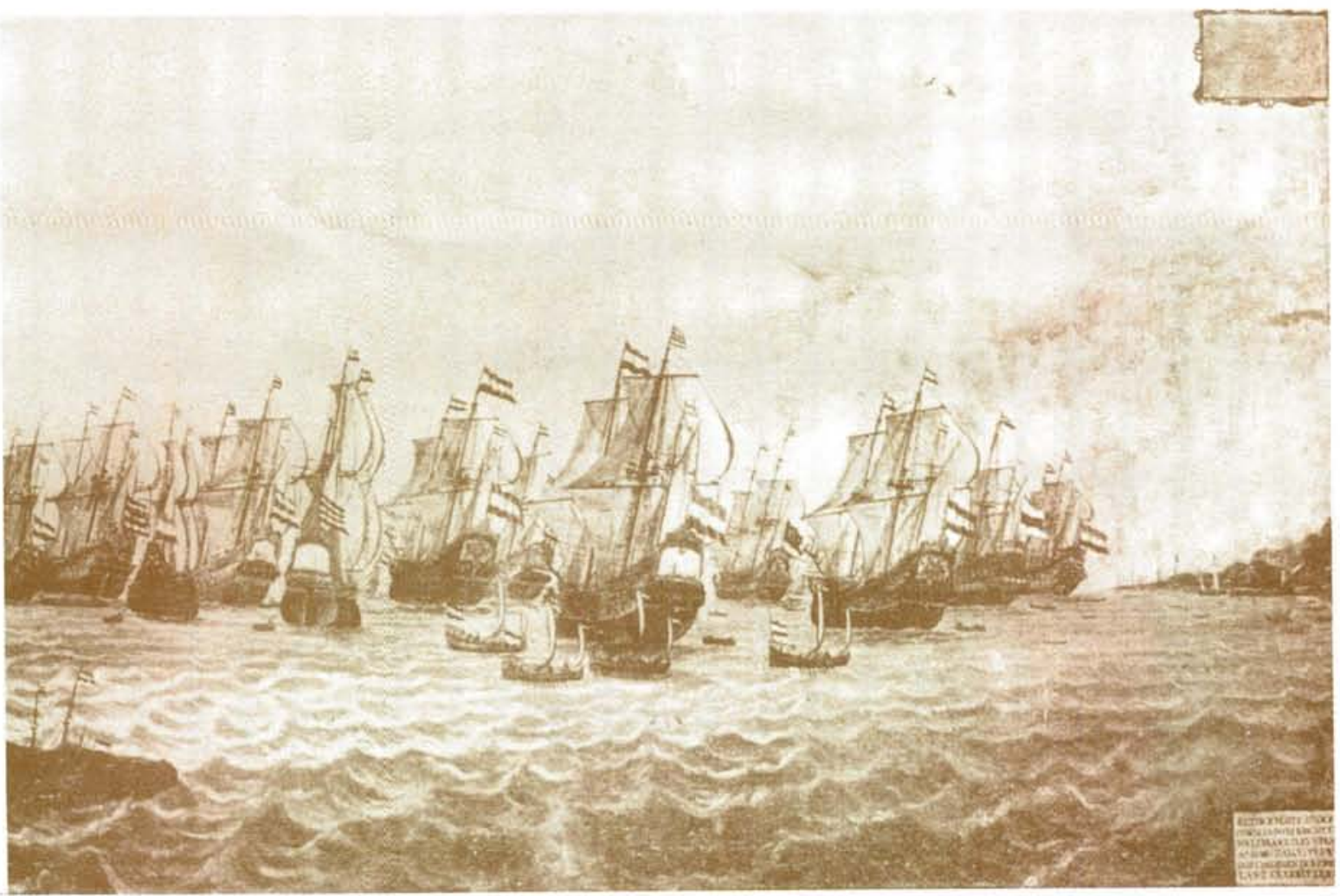

Die VOC se retoervloot van 1648 naby die elland Onrust, by Batavia. Hierdie vloot was onder bevel van kommandeur Wollebrand G. de Jong. Van Rlebeeck was aan boord van die skip "De Coninck van Polen" 
verkoopers" hulle verskyning in Amsterdam en ander Nederlandse hawens gemaak. Hulle het werkloses en behoeftiges, wat werk en rykdom in Nederland gesoek het, aangehou. Tydens die daaropvolgende gesprek is die toekomstige rekrute kos en inwoning aangebied tot tyd en wyl die volgende vloot sou uitvaar. Die koste vir hierdie onderhoud en onderdak sou van die soldaat of matroos se toekomstige soldy afgetrek en vereffen word. Dié mondelinge ooreenkoms is in 'n skriftelike skuldbewys of "transportbrief" bekragtig.

' $n$ Voornemende soldaat het ongeveer nege gulden per maand verdien, terwyl sy skuld by die ronselaar ongeveer 150 gulden bedra het. Vir ' $n$ matroos was die skuld gewoonlik 200 gulden, terwyl 'n toekomstige offisier se skuld deurgaans 300 gulden was. Skrywers het die metodes van die "zielverkoopers" as gewetenloos bestempel. Wat die behandeling van die rekrute deur die ronselaars betref, merk Boxer o.m. op:

"While awaiting the day when the drum was beaten to announce enlistment for the Company's naval or military service, the recruits were kept in conditions which at times recall those of the barracoons for 'black ivory' in the West African slave-trade" (p. 82).

\section{Die lewe aan boord}

Aan boord was daar, behalwe matrose en soldate, ook offisiere, amptenare en passasiers. Laasgenoemde twee groepe is beter behandel en gehuisves as die ander. Matrose en soldate moes met ' $n$ eed gehoorsaamheid aan die inhoud van die sogenaamde Artikelbrief sweer. Voor inskeping is meer as sestig voorskrifte of artikels in verband met verpligte gebed, eerbied vir die Woord, gehoorsaamheid, voeding, die hantering en behandeling van wapens, diensverrigting, waghou, muitery, geweldpleging, dronkenskap, dobbel, vegpartye, brandgevaar, vrouens aan boord, diefstal, verkoop van tabak en brandewyn ensovoorts voorgelees en die ooreenkomstige straf, in geval van oortreding, daarby vermeld.

$\mathrm{Na}$ aflegging van die eed is die bagasie ingeskeep en het almal aan boord gegaan.

Daar is, gewoonlik by die eiland Texel (die voorhawe van Amsterdam), gewag tot voldoende skepe aanwesig was om ' $n$ vloot te vorm. Loodse het daarvoor gesorg dat die vloot veilig die oop see bereik en daarna het die reis na die Kaap die Goeie Hoop en Batavia begin.
Die geestelike versorging aan boord was die taak van 'n sieketrooster of ' $n$ predikant. Hulle het in gebed voorgegaan en op Sondae en biddae die godsdiensoefening gelei. Verder het hulle siekes en gewondes geestelik versorg. Daar was nie altyd volledig opgeleide leraars aan boord nie.

Wat die geneeskundige hulp betref was daar gewoonlik ook geen gekwalifiseerde mediese dokters aan boord nie. Chirurgyns het aan die vaste wal en aan boord die skeerpraktyk beoefen, wonde verbind, breuke behandel en klein operasies verrig. Vir hulle werk aan land het hulle 'n eksamen, die "huisproef" afgelê, terwyl die ligtere "zee-examen" vir werksaamhede aan boord afgeneem is. Aan boord het hulle, soos vermeld, beserings behandel. Aangesien beserings maklik in gangreen of kouevuur ontaard het, het hulle voorkeur aan afsetting van ledemate gegee.

Verder het hulle veral drie soorte siektes, naamlik van die asemhalingsorgane, dié wat veroorsaak was deur wanvoeding aan boord, en verskillende koorssoorte behandel.

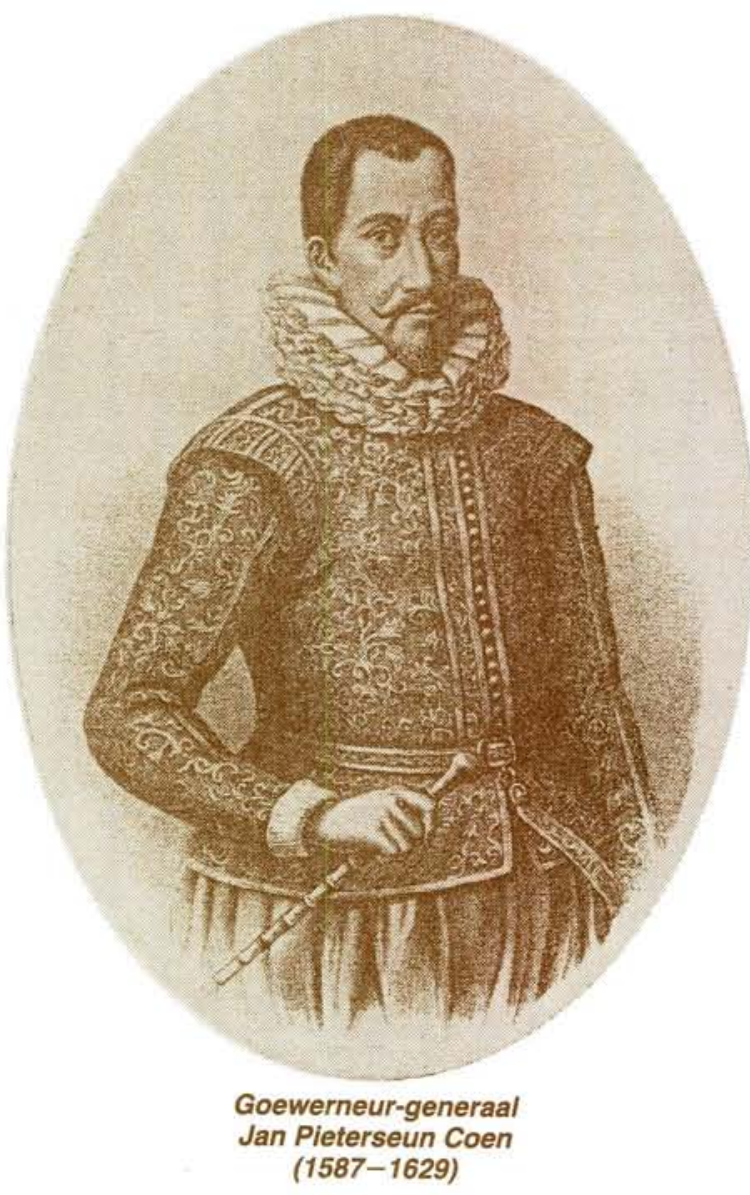


Siektes van die asemhalingsorgane het veral voorgekom aan boord van vlote wat in die Europese winter (Desember) uit die koue na die suide vertrek het. Voor hul aankoms by die Kanariese eilande het dié siektes uitgebreek.

Skeurbuik het by die Kaapse Verdiese eilande begin en toegeneem tot die aankoms by die Kaap die Goeie Hoop of Mauritius.

Van die skip Galiasse, wat vergesel van 'n sestal skepe op 19.3.1627 van Texel vertrek het, is bekend dat dié skip, met goewerneur-generaal Jan Pieterseun Coen (1587-1629) aan boord, 'n vinnige seiler was. Dit het voor die ander skepe in Tafelbaai aangekom en ongeveer 100 siekes aan boord gehad.

Coen het, aan land, 'n tentekamp vir die siekes laat opslaan. Veertig skeurbuiklyers moes aan land gedra word, terwyl die ander "dick van beenen ende blaeu utgeslaghen", nog kon stap. Vars voedsel, vis en pikkewynvleis van Robbeneiland, sowel as vrugte en groente, het die pasiënte almal laat genees.

Verder was daar buikloop, geslagsiektes, verkoues, keelontsteking, sowel as borsvlies- en longaandoenings wat aandag geniet het. Daar was ook siektes wat uit onvoldoende of ondoeltreffende voeding, eentonige kos en ontoereikende geneesmiddels voortgespruit het, terwyl behoorlike versorging dikwels ontbreek het.

Doodsoorsake tydens die seereis het voortgevloei uit ongelukke aan boord, beperkte ruimte vir die bemanning en geringe vars lug, deur luike en geskutpoorte, in tropiese gebiede. Ondrinkbare water het ook ' $n$ rol gespeel.

Die navorser dr. D. Schoute het in sy studie De geneeskunde in den dienst der Oost-Indische Compagnie in Nederlands-Indië (Amsterdam, 1929) onder andere verklaar dat die 17 de eeuse mediese terminologie hom verhinder het om siektes noukeurig vas te stel. Boonop het feitlik nie alle chirurgyns ' $n$ dagboek van hulle werksaamhede gehou nie. Hy kon nietemin vasstel dat die water dikwels vol wurmpies en nouliks drinkbaar was. Gevolglik het die bemanning sy toevlug tot allerhande soorte alkoholhoudende dranke geneem, terwyl "watermakers" op sommige skepe met 'n distilleerketel soet water uit seewater berei het.

Schoute het bereken dat tussen 1691 en 1696 sterfgevalle op skepe sonder ' $n$ distilleerketel aanmerklik hoër was. Ook kon hy vasstel dat die sterftes tussen 1624 en 1632, aan boord van 15 skepe, tussen Nederland en Batavia, 368 op 2250 , met ander woorde $14,4 \%$ was. Op 26 skepe is, tussen 1642 en 1648, 246 van die 3362 lede van die bemanning oorlede. Dit was, op 'n gemiddelde reisduur van 185 dae, $8 \%$. Die reis van laasgenoemde 26 skepe het van 136 tot 419 dae geduur.

Prof. C.R. Boxer het vasgestel dat sterftes gedurende die laaste jare van die 18 de eeu gestyg het. Tussen 1768 en die volgende jare was daar op 27 skepe, met ' $n$ totale bemanning van 5971 . 959 sterfgevalle. Hy haal tewens die skrywer O.F. Mentzel (1709-1801) aan wat opgemerk het dat gesonde lug en vars vleis aan die Kaap die Goeie Hoop gewoonlik meer tot die herstel van siek soldate en matrose bygedra het as die medisyne van die chirurgyns of dokters.

Voedsel is drie maal per dag voorsien en het uit brood, kaas, vleis, spek, stokvis, gort en peulvrugte bestaan. Verder is bier en brandewyn verskaf. Soggens was dit gort met botter en bier, op Sondae en Donderdae ' $n$ half pond spek of vleis en ertjies. Op Maandae, Dinsdae, Woensdae, Vrydae en Saterdae was daar smiddags en saans wit ertjies en stokvis. Die rantsoene botter en kaas is weekliks uitgedeel.

Dit is duidelik dat die kos eentonig was. Terselfdertyd is bederf nie uitgesluit nie.

Die tug aan boord was 'n uitvloeisel van die toepassing van die Artikelbrief, wat met verloop van jare aangevul is. Voorbeelde van strawwe was die volgende: Opsluiting in boeie ("ysters"), met water en brood as enigste voedsel. Die gestrafte is in die voorstewe van 'n skip toegesluit. "Laarzen" was 'n straf wat toegedien is deur 'n oortreder met 'n natgemaakte tou te laat slaan. Verder is gevonnistes van die ra ('n lang rondhout wat kruisgewys aan ' $n$ mas bevestig is) in die see laat val. Die slagoffer se hande was op sy rug vasgebind en deur die val is sy ledemate gebreek en gekneus. Die ergste straf was die doodstraf. Dan is die skuldige aan die ra opgehang. ' $n$ Gestrafte matroos of soldaat is gekielhaal deur hom onder die skip deur te trek.

Toesig oor die gevangenes aan boord is deur die provoos uitgeoefen. Hy moes die gevangenes versorg, gesel en brandmerk.

Aan die Kaap die Goeie Hoop is hierdie ampte- 


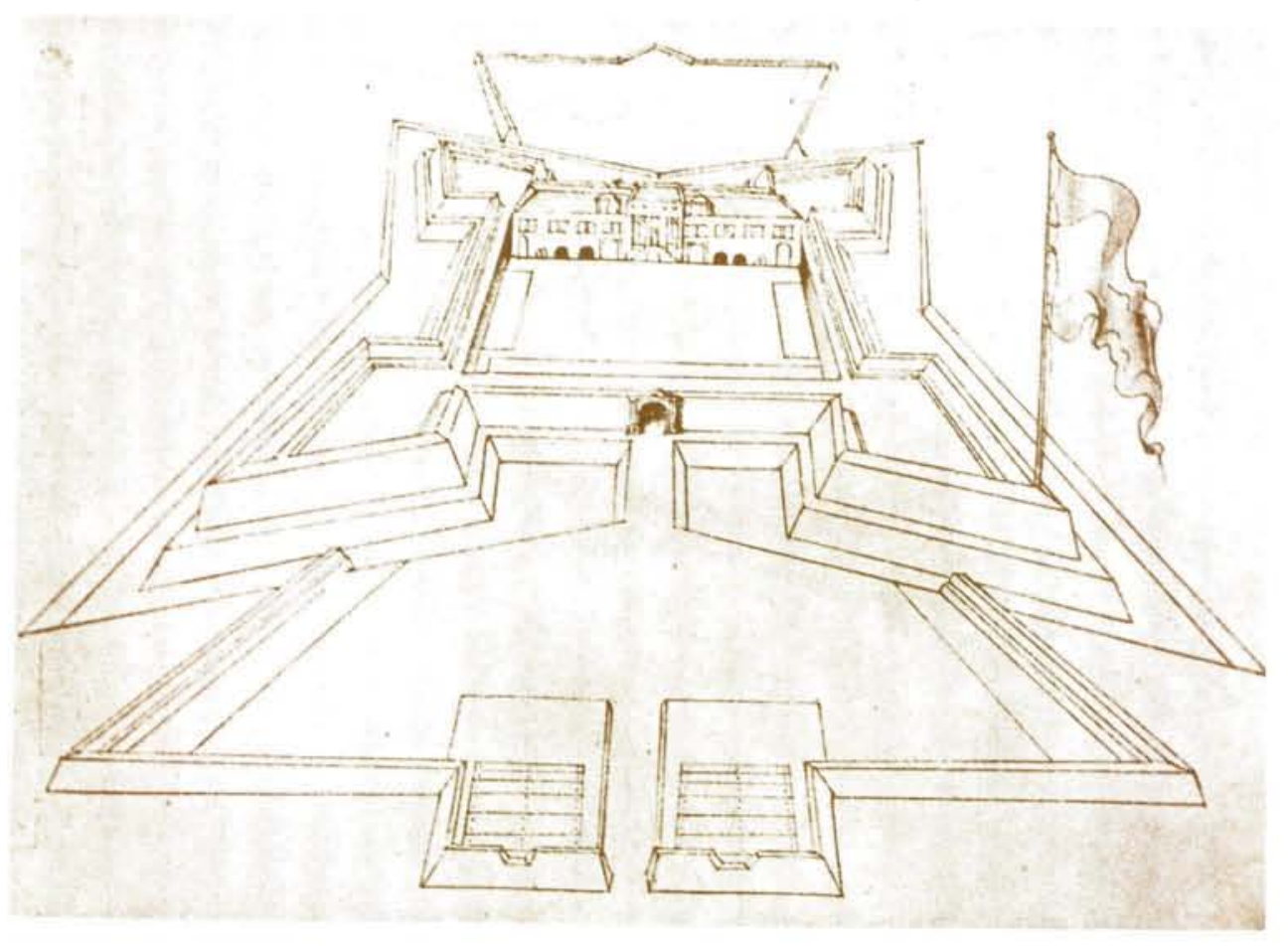

Die fort "De Goede Hope" aan Tafelbaai

naar "geweldiger", afgelei van 'n "provoost geweldige", genoem.

Ook aan land was, volgens hedendaagse begrippe, die strawwe onmenslik streng. Dit blyk onder andere uit 'n honderdtal hofsake van die Kaapse Raad van Justisie (1652-1672), wat onder die titel Uit die Raad van Justisie, 1652-1672 (Pretoria, 1986) deur dr. A.J. Böeseken geredigeer en in die "Suid-Afrikaanse Argiefstukke-reeks" gepubliseer is. Daar is geredeneer dat streng tugmaatreëls die enigste middel was om oortreders in bedwang te hou en in haar inleiding tot die genoemde publikasie het dr. Böeseken tot die gevolgtrekking gekom dat die Raad van Justisie sonder willekeur reg laat geskied het.

\section{Die seereis}

$\mathrm{Na}$ die Kanariese eilande was aanvalle deur seerowers of, in oorlogstyd, deur vyandelike vlote, gewoonlik iets van die verlede. Die gewone, eentonige lewe aan boord is met skeepswagte, daelikse godsdiensoefeninge en die weeklikse uitdeling van rantsoene afgewissel. Die drinkwater het geleidelik ondrinkbaar begin word, terwyl skeurbuik uitgebreek het. Sterfgevalle het begin voorkom en lyke is aan die golwe toevertrou.
Soms het die skepe die eiland Sint Helena aangedoen. Daar is vars water, slagvee, voëls, groente, vrugte, vis en sout verkry.

Portugese, Engelse en Nederlanders het dié eiland met sy aangename klimaat, wat in 1633 deur Nederlanders in besit geneem is, besoek. Maar te veel besoekers, verwilderde skeepshonde en die vernielsug van matrose en soldate, het hierdie verversingspos waardeloos begin maak.

Vandaar het die skepe na die Kaap die Goeie Hoop geseil of daar verby gegaan omdat weersomstandighede ongunstig was. Soms is Tafelbaai en Saldanhabaai met mekaar verwar.

Reeds in 1619 het Nederlandse stemme opgegaan om ' $n$ verversingspos aan die Kaap te stig. Die stranding van die Nieuw-Haarlem, in 1647 . sou tot die stigting van 1652 lei toe die stigterstaak, in opdrag van die VOC, deur Jan van Riebeeck uitgevoer is.

'n Verblyf van siekes aan Tafelbaai het wondere verrig en baie menselewens kon gered word. Só het "de Indische Zeeherberg", die benaming is van kommissaris-generaal Jacob Abraham Uitenhage de Mist (1749-1823), 'n ware toevlugsoord vir siek Kompanjiedienaars geword. 
Ten slotte die volgende gedagte van prof. C.R. Boxer, aan die einde van die VOC-seereis na die Kaap die Goeie Hoop, die halfwegstasie op pad na Batavia:

"... the life of a Dutch sailor was apt to be nasty, brutish and short - particularly for those who sailed before the mast to the East and West Indies.

But this was not, of course, invariably so. If many ships suffered severely on the long voyage between the Texel and Batavia, others made it without the loss of a man and with all on board healthy and fit.

If the food was often bad, and the discipline sadistically severe, vocal music seems to have done much to sooth the savage breast of Jan Maat."
C.R. Boxer: The Dutch Seaborne Empire 1600-1800 (London, 1965, p. 83).**

* Kol (dr) Jan Ploeger, SSO Argief en Navorsing, SAW, 1964-73. Staatshistorikus, RSA, 1973-1983.

* In 1628 is, in opdrag van die VOC, in Amsterdam met die bou van die bewapende handelskip, die "Batavia"' begin. Tydens sy eerste reis na die destydse Oos-Indië, op 4 Junie 1629, het die "Batavia" op ongeveer 50 seemyl voor die weskus van Ausitraliè op die klippe geloop. ' $n$ Groot deel van die bemanning kon gered word, maar die skip was 'n verlies. Hierdie ramp het op ' $n$ afstand van 1300 seemyl van Batavia plaasgevind.

In 1980 het belangstellendes in Nederland met ' $n$ studie van die 17 de eeuse skeepsbou begin. Daarna is, op 12.9.1985, die vereniging die "Stichting Nederland bouwt V.O.C.-Retourschip" gestig. Op 4.10 .1985 is die kiel van die toekomstige nuwe "Batavia" in Lelystad gelê. Vandag word die boutyd van so 'n vaartuig op vier jaar en ses maande bereken. 